\title{
Regional spatio-temporal trends in Caribbean coral reef benthic communities
}

\author{
Virginia G. W. Schutte ${ }^{1,3, *}$, Elizabeth R. Selig ${ }^{1,2,4}$, John F. Bruno ${ }^{1}$ \\ ${ }^{1}$ Department of Marine Sciences, The University of North Carolina at Chapel Hill, 340 Chapman Hall CB\# 3300, Chapel Hill, \\ North Carolina 27599-3300, USA \\ ${ }^{2}$ Curriculum for the Environment and Ecology, 207 Coastes Building CB\# 3275, The University of North Carolina at Chapel \\ Hill, Chapel Hill, North Carolina 27599-3275, USA \\ ${ }^{3}$ Present address: Odum School of Ecology, The University of Georgia, 140 E. Green St., Athens, Georgia 30602-2202, USA \\ ${ }^{4}$ Present address: Center for Applied Biodiversity Science, Conservation International, 2011 Crystal Drive, Suite 500, \\ Arlington, Virginia 22202, USA
}

\begin{abstract}
Coral cover has declined on reefs worldwide with particularly acute losses in the Caribbean. Despite our awareness of the broad-scale patterns and timing of Caribbean coral loss, there is little published information on: (1) finer-scale, subregional patterns over the last $35 \mathrm{yr}$, (2) regional-scale trends since 2001, and (3) macroalgal cover changes. We analyzed the spatiotemporal trends of benthic coral reef communities in the Caribbean using quantitative data from 3777 coral cover surveys of 1962 reefs from 1971 to 2006 and 2247 macroalgal cover surveys of 875 reefs from 1977 to 2006. A subset of 376 reefs was surveyed more than once (monitored). The largest $1 \mathrm{yr}$ decline in coral cover occurred from 1980 to 1981, corresponding with the beginning of the Caribbean-wide Acropora spp. white band disease outbreak. Our results suggest that, regionally, coral cover has been relatively stable since this event (i.e. from 1982 to 2006). The largest increase in macroalgal cover was in 1986, 3 yr after the regional die-off of the urchin grazer Diadema antillarum began. Subsequently, macroalgal cover declined in 1987 and has been stable since then. Regional mean $( \pm 1 \mathrm{SE})$ macroalgal cover from 2001 to 2005 was $15.3 \pm 0.4 \%(\mathrm{n}=1821$ surveys). Caribbeanwide mean $( \pm 1 \mathrm{SE})$ coral cover was $16.0 \pm 0.4 \%(\mathrm{n}=1547)$ for this same time period. Both macroalgal and coral cover varied significantly among subregions from 2001 to 2005, with the lowest coral cover in the Florida Keys and the highest coral cover in the Gulf of Mexico. Spatio-temporal patterns from the subset of monitored reefs are concordant with the conclusions drawn from the entire database. Our results suggest that coral and macroalgal cover on Caribbean reef benthic communities has changed relatively little since the mid-1980s.
\end{abstract}

KEY WORDS: Coral cover $\cdot$ Macroalgae $\cdot$ Coral disease $\cdot$ Coral bleaching

\section{INTRODUCTION}

Based on a recently published global map of the magnitude and geographic extent of 17 anthropogenic threats, Halpern et al. (2008) argued that coral reefs are one of the world's most heavily impacted marine ecosystems. This finding is consistent with a vast body of literature documenting the global degradation of tropical reefs over the last several decades (Wilkinson 1992, Grigg 1994, Gardner et al. 2003, Bruno \& Selig 2007, Edmunds \& Elahi 2007). Coral loss can lead to reductions in fish abundance and diversity (Jones et al. 2004, Pratchett et al. 2008) and declines in topographical complexity (Alvarez-Filip et al. 2009). Coral loss is also associated with compensatory increases in the abundance of several other taxa, including sponges, 
gorgonians, and macroalgae (Hughes 1994, Aronson et al. 2002, Norström et al. 2009). A wide variety of causes and human activities have been implicated in driving these changes, including overfishing, increasing ocean temperatures, coral disease and predator outbreaks, and poor land-use practices that lead to sedimentation and nutrient pollution (Endean 1977, Jackson et al. 2001, Hughes et al. 2003, Fabricius 2005, Hoegh-Guldberg et al. 2007).

Although the key drivers of coral loss have been identified, there is no consensus on their relative importance and how this varies in space and time (Grigg \& Dollar 2005, Precht et al. 2005). Quantifying the spatio-temporal changes in coral reef benthic communities at regional and decadal scales can lead to a broader understanding of the patterns and causes of reef degradation and provide information which will result in more effective management actions (Côté et al. 2005).

The purpose of the present study was to quantify the regional-scale trends in coral and macroalgal cover on Caribbean coral reefs over the last $35 \mathrm{yr}$ in each of 7 subregions (Fig. 1A). Our study builds on previous analyses of benthic changes on particular reefs (Edmunds \& Elahi 2007), whole islands (Hughes 1994), and a meta-analysis of the entire region (Gardner et al. 2003). Although the broad-scale patterns and timing of Caribbean coral loss were discussed in Gardner et al. (2003), there is no published information on regionalscale trends for macroalgal cover or for coral cover since 2001. Our analysis was based on data from 3777 surveys of 1962 reefs performed between 1971 and 2006-the largest compilation of quantitative Caribbean reef surveys to date.

\section{MATERIALS AND METHODS}

All analyses were based on quantitative in situ surveys of subtidal coral reefs in the Caribbean basin that measured the percentage of the bottom covered by living scleractinian coral tissue. We grouped these survey sites into 7 subregions, which were similar to previous delineation schemes and were based on areas of similar biodiversity and biogeography, major bathymetric changes, or
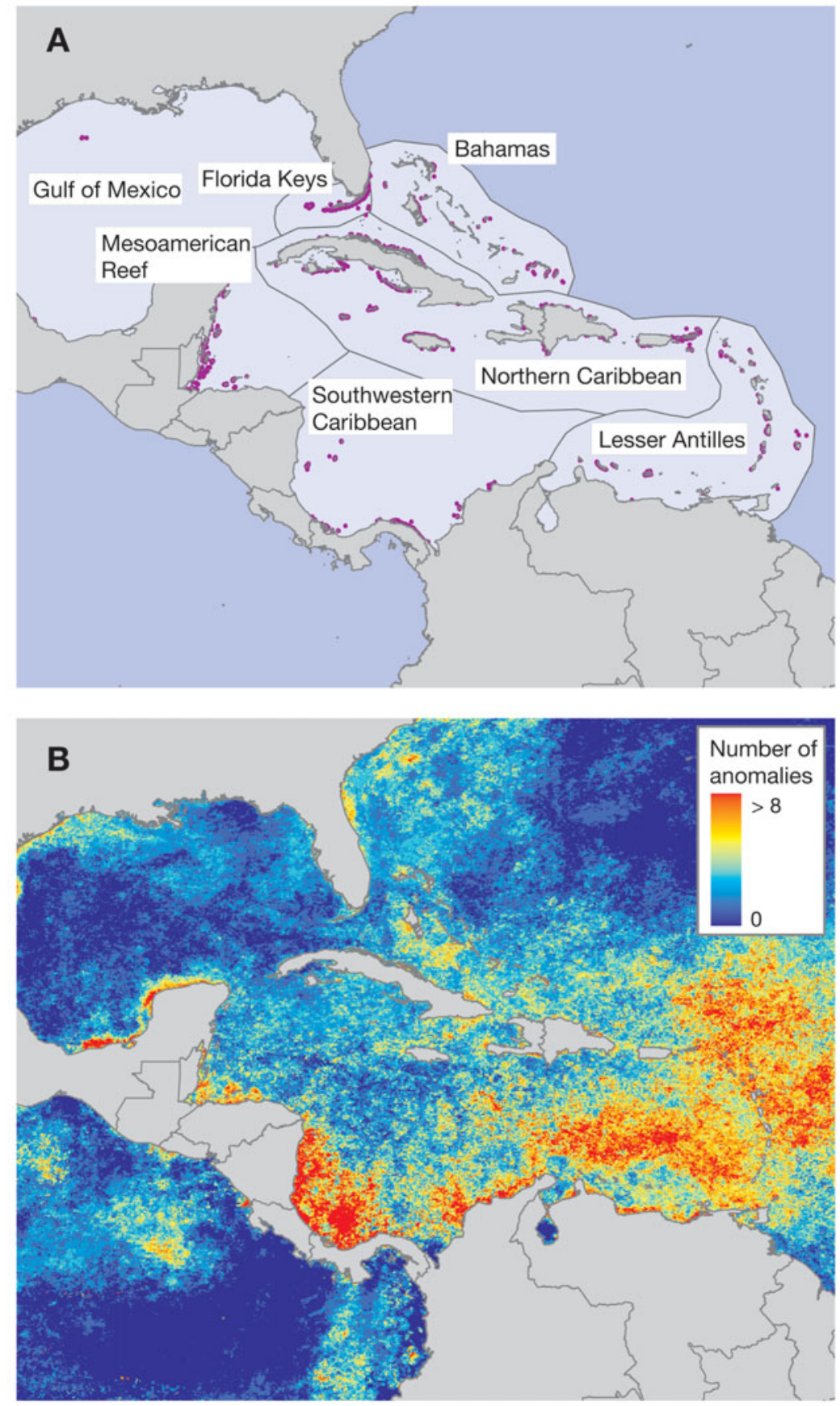

Fig. 1. (A) Locations of survey sites (purple dots; $n=1667$ ) and delineations of the 7 subregions used in our analyses. The 295 sites for which we could not obtain exact coordinates are not shown. (B) Number of thermal stress anomalies during 2005. Sea surface temperature data were derived from the Advanced Very High Resolution Radiometer sensor and were processed to a resolution of approximately $4.6 \mathrm{~km}$ at the equator. An anomaly is defined as $1^{\circ} \mathrm{C}$ more than the typical maximum climatological week defined for each grid cell (see also Text S3 in the supplement, www.int-res.com/articles/suppl/m402p115_app. pdf) 
management regimes (Fig. 1 $\mathrm{A}_{i}$ Spalding et al. 2007). The coral and macroalgal cover survey database was compiled by searching the scientific literature using a variety of search engines (e.g. ISI Web of Science and Google Scholar) using terms including 'Caribbean' and 'coral cover'. We also examined every issue of Coral Reefs, Atoll Research Bulletin, the Proceedings of the Colloquium on Global Aspects of Coral Reefs (Ginsburg 1993), and the Proceedings of the International Coral Reef Symposiums. When cover data were presented in graphical form, we used ImageJ (Rasband 2006) to extract the raw data (the percent cover). In addition, we obtained survey data directly from several monitoring programs (Text S1, Fig. S1 \& Table S1 in the supplement, www.int-res.com/articles/suppl/ m402p115_app.pdf), including the Florida Coral Reef Evaluation and Monitoring Project (CREMP; data comprise $35.6 \%$ of surveys and $13.1 \%$ of sites), the Atlantic and Gulf Rapid Reef Assessment (AGRRA) Program (17.1\% of surveys and $30.3 \%$ of sites), and Reef Check ( $16.5 \%$ of surveys and $22.8 \%$ of sites).

The database included 3777 coral cover surveys from 1962 sites surveyed between 1971 and 2006 (Text S1 \& Table S2 in the supplement, www.int-res.com/articles/ suppl/m402p115_app.pdf). We pooled observations across depths ( 1 to $30 \mathrm{~m}$ depth, $8.2 \pm 0.08 \mathrm{~m}$, mean \pm $1 \mathrm{SE}$; Fig. S2 in the supplement, www.int-res.com/ articles/suppl/m402p115_app.pdf) and reef zones for our analyses because there was little variation in survey depth among subregions or years and there was no relationship between depth and cover (Text S2 \& Fig. S3 in the supplement, www.int-res.com/articles/ suppl/m402p115_app.pdf). The cover of Millepora spp. (hydrozoans) was included in the total live coral cover value for 181 surveys ( $4.1 \%$ of all surveys). Macroalgal cover, including both fleshy and calcifying macroalgae (sensu Steneck 1988), was measured in 2247 surveys on 875 reefs (58.4 and $44.6 \%$ of the total, respectively). We did not include cover from turf or coralline encrusting algae. In $64.6 \%$ of surveys, benthic cover was measured in situ using related techniques such as the AGRRA Program methodology (Lang 2003) and point intercept cover estimates (Hodgson et al. 2006, Lam et al. 2006). For the other $35.4 \%$, the substrate was recorded with video or still photographs (Edmunds \& Bruno 1996), which were analyzed in the laboratory using image analysis software or the point count technique (Aronson et al. 2002, Idjadi \& Edmunds 2006, Lam et al. 2006, Rogers \& Miller 2006).

Annual sample sizes for the whole region ( 200 to 400 surveys; Fig. 2) and for many subregions (Table S1) over the last decade are quite large, and most survey sites were more or less randomly or haphazardly selected (particularly with respect to the hypotheses being tested in this analysis). In other words, we used survey data regardless of the original research purpose. Therefore, our analyses are likely representative of the broadscale trends on benthic reef communities, particularly since the mid-1990s. Yet meta-analyses of field surveys such as this have a number of limitations, and several caveats need to be considered when interpreting the results (Bruno \& Selig 2007). First, year-to-year variations in which sites are sampled can cause apparent shortterm temporal trends that are likely sampling artifacts and not real phenomena. As in any long-term analysis, short-term and temporary fluctuations are expected, may not be real, and should not be over-interpreted.

Second, for a variety of reasons, some sites and subregions have been sampled far more intensively than others. We used a repeated measures linear regression analysis to test the null hypothesis that there was no relationship between percent coral or macroalgal cover and time (using Stata Version 9.1, STATA). This test was based on the individual trajectories of the 7 subregions rather than pooled data for each year. Performing this analysis on yearly subregional averages equalizes the influence of each subregion. However, it does not remove the influence of highly sampled sites on subregional values. Additionally, some important locations were sampled comparatively sparsely relative to their size, e.g. Belize. Therefore, the regional and subregional trends may not be representative of all parts of the Caribbean. Our general trends also might differ from the true, but unknowable, population values. The population-level trends we quantified are not meant to represent the trajectory of any individual reef. Additionally, trends from the early years of the database should be interpreted with great caution given their relatively small annual sample sizes. We still know very little about the natural baselines of Caribbean reefs and even less about their state even in the near-past, e.g. the 1960s. Thus, putting our results into a broader historical context is very difficult. It is possible that Caribbean reefs began to degrade long before we began surveying them (Pandolfi et al. 2003), in which case the actual degree of degradation is much greater than we can currently quantify.

The database largely consisted of reefs surveyed only once, but included 376 reefs surveyed in 2 or more years. We analyzed this subset of monitored reefs separately from the entire database, restricting the analysis to surveys performed between 1996 and $2006(n=331$ reefs; Table S3 in the supplement, www.int-res.com/ journals/articles/m402p115_app.pdf), because few reefs were monitored before this time period. Repeated-measures regression analysis was used to determine whether coral or macroalgal cover changed significantly from 1996 to 2006 . We performed separate analyses for each subregion and also an analysis of all the monitoring data combined. 


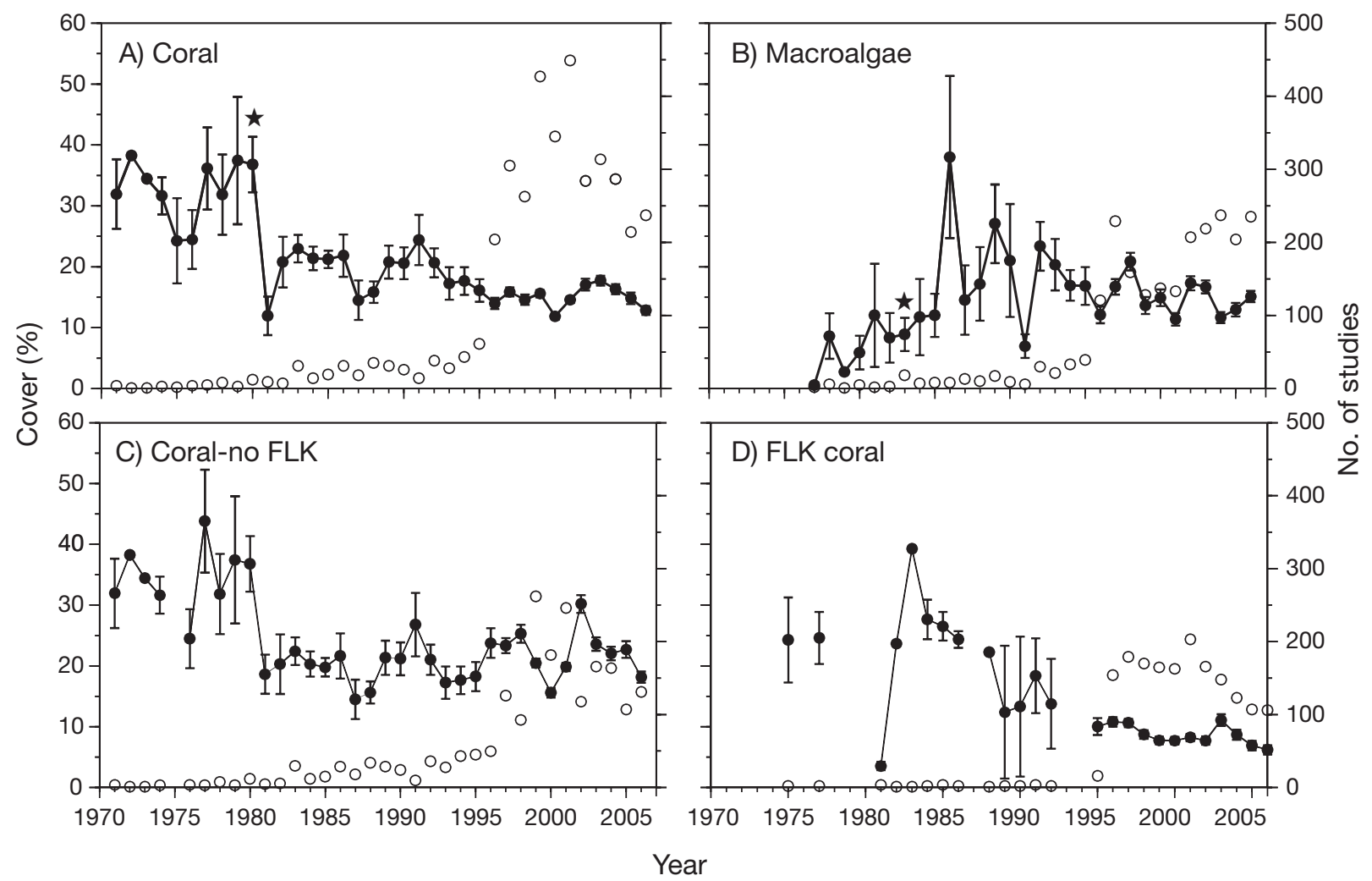

Fig. 2. Annual cover values $( \pm 1 \mathrm{SE}$, closed circles, left $y$-axis) and site sample sizes (open circles, right $y$-axis) for (A) mean coral cover for all sites in the Caribbean basin $(n=1962$; star: 1980, the year in which Hurricane Allen struck and white band disease outbreaks began); (B) mean macroalgal cover for all sites for which data were available $(\mathrm{n}=875$; star: 1983, the year in which the Diadema antillarum die-off began); (C) mean coral cover for all sites in the greater Caribbean except those in the Florida Keys $\left(F_{L K} \mathrm{n}=1515\right) ;$ and $(\mathrm{D})$ mean coral cover for all sites in the FLK subregion $(\mathrm{n}=447)$

\section{RESULTS AND DISCUSSION}

\section{Regional temporal trends}

Numerous studies indicate that Caribbean reef benthic communities changed dramatically in the 1980s (Hughes et al. 1985, Carpenter 1990, Liddell \& Ohlhorst 1992, Hughes 1994, Gardner et al. 2003). Despite the general perception that Caribbean reefs have continued to degrade, the broad-scale cover of hard corals and macroalgae appears to have changed very little since at least the mid-1980s. Our analysis suggests that the regional coral cover average has not changed significantly since the 1981 Acropora spp. mass mortality (i.e. from 1982 to 2006, $p=0.99$, based on repeatedmeasures regression of annual subregional means; Fig. 2A). This pattern of regional stasis does not contradict studies that have documented recent, i.e. post1980s, coral loss on individual reefs (e.g. Aronson et al. 2002, Edmunds 2007) and in some subregions such as the Florida Keys (Fig. S4 in the supplement, www. int-res.com/articles/suppl/m402p115_app.pdf; Porter \&
Meier 1992, Maliao et al. 2008). Instead it suggests that local losses on some reefs have apparently been roughly balanced by local coral recovery on other reefs. In other words, the observed pattern of regional stasis is probably a dynamic equilibrium, masking greater spatio-temporal variance in benthic community structure at finer spatial scales. Additionally, because we were only able to analyze broad-scale patterns in total coral and macroalgal cover, we could not evaluate other reef characteristics such as trophic complexity (Paddack et al. 2009), reef rugosity (AlvarezFilip et al. 2009), or changes in species composition (e.g. Aronson et al. 2004), which may indeed have changed during the study period and are also important indicators of coral reef health.

Disturbances before the mid-1980s caused substantial regional losses in coral cover. Caribbean-wide coral cover averages were highest from 1971 to 1980 (Fig. 2A). Annual regional means during this period ranged from $\sim 25$ to $40 \%$ ( $\mathrm{n}=43$ surveys), which is somewhat lower than generally assumed (Gardner et al. 2003). Our results suggest that regional absolute coral cover declined by $\sim 18 \%$ between 1972 , the year with the highest yearly coral cover mean $(38.3 \%, n=1$ 
survey), and $1982(20.8 \pm 4.2 \%, \mathrm{n}=7$ surveys $)$, when the current period of regional stasis began (Fig. 2A). However, the annual coral cover means during this period are based on a small number of surveys (Table S2) and it is possible that the historical regional baseline was higher. The largest $1 \mathrm{yr}$ decline in coral cover $(24.9 \pm 3.2 \%$ absolute coverage $)$ took place from 1980 to 1981, coincident with and presumably due to the regional Acropora spp. die-off from the white band disease epizootic (Aronson \& Precht 2001, 2006) and the passage of Hurricane Allen through Jamaica (Woodley et al. 1981), where 9 of the 21 surveys conducted in 1980 and 1981 were performed.

Just over half of the coral cover surveys had accompanying macroalgal cover values; our database included 2247 macroalgal surveys conducted between 1977 and 2006. Macroalgal cover did not change between 1987 and 2006 ( $p=0.13$; Fig. 2B), although the small number of quantitative surveys in the 1980s and early 1990s makes estimates of subregion-specific macroalgal trends during this period less reliable (Table S2). It is possible that some other rarely measured attribute of macroalgae changed during the period of stasis, e.g. biomass, height, or composition, although macroalgal cover is generally a good predictor of macroalgal biomass (Miller et al. 2003).

The regional mean coverage of macroalgae increased dramatically in 1986 (26.0 $\pm 13.3 \%$; Fig. 2B) following the Caribbean-wide die-off of the sea urchin Diadema antillarum in 1983 and 1984 (Hughes et al. 1985, Lessios 1988). Mean macroalgal cover before the $D$. antillarum die-off (based on 37 surveys performed from 1977 to 1983 ) was $8.0 \pm 1.6 \%$. In 1986, macroalgal cover increased to $38.1 \pm 13.3 \%$ ( $\mathrm{n}=8$ surveys). However, it declined again to $14.5 \%$ in $1987( \pm 5.7, \mathrm{n}=13$ surveys) and the regional mean remained below $20 \%$ for most years between 1987 and 2006. The drop in macroalgal cover following the spike in 1986 could be due to compensatory population increases or behavioral responses by other fish and urchin grazers to the loss of the once dominant herbivore, D. antillarum (Aronson et al. 2000, Haley \& Solandt 2001). Populations of $D$. antillarum have since recovered on some Caribbean reefs (e.g. Carpenter \& Edmunds 2006, Myhre \& Acevedo-Gutiérrez 2007), which could explain the general absence of macroalgal cover changes since 1987. Conversely, the 1986 spike in macroalgal cover could be an artifact of non-random site selection; many macroalgal cover studies conducted in the mid1980s focused on reefs that experienced significant losses in coral cover or were designed to document the indirect effects of the D. antillarum die-off (e.g. Hughes 1994).

The combined multi-decade, regional patterns of changes in coral and macroalgal cover indicate that, although the region has experienced substantial coral losses, there has not been a concomitant increase in macroalgal cover (Fig. 3). Almost half (48.9\%) of the 2247 macroalgal surveys documented a higher percentage of macroalgal cover than coral cover, but macroalgal cover has rarely exceeded $50 \%$ (just $5.2 \%$ of surveys). The observed regional increase in macroalgal cover in 1986 occurred 5 yr after the collapse of coral cover in 1981, supporting the argument that coral loss in the 1980s was not caused by an increase in macroalgal cover (Aronson \& Precht 2006, Bruno et al. 2009).

The relationship between coral and macroalgal cover on reefs over time can be divided into 3 temporal categories (Fig. 3): (1) the late 1970s, the baseline for the present study; (2) the 1980s and early 1990s, after the Acropora spp. and Diadema antillarum disease outbreaks; and (3) from 1993 to 2006, a period of postdisease stability. We pooled the annual means within each temporal period in order to compare the 3 periods, and the greatest coral cover loss occurred from Time Period 1 to Time Period 2. There was not a longterm increase in macroalgal cover proportional to the coral cover loss in the 1980s.

\section{Recent spatial patterns}

Recent (2001 to 2005) macroalgal cover varied significantly among subregions (ANOVA, p < 0.0001; Fig. 4) and ranged from $6.2 \pm 4.0 \%$ ( $\mathrm{n}=16$ surveys) in the Gulf of Mexico to $22.8 \pm 1.6 \%$ ( $n=100$ surveys $)$ in the south-

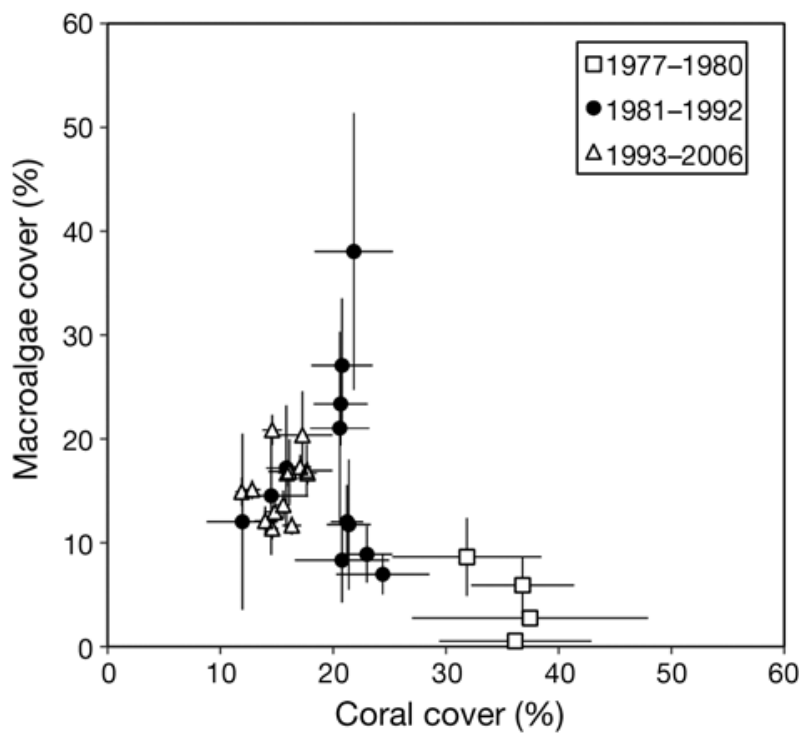

Fig. 3. Average annual coral and macroalgal cover values from 1977 to 2006. Horizontal and vertical lines represent $1 \mathrm{SE}$. The 3 points from the 1981 to 1992 group that are clumped with the 1993 to 2006 values are from 1981, 1987, and 1988 
western Caribbean. The region-wide mean cover of macroalgae from 2001 to 2005 was $15.3 \pm 0.4 \%$ ( $\mathrm{n}=$ 1821 surveys), while mean coral cover was $16.0 \pm 0.4 \%$ ( $\mathrm{n}=1547$ surveys). Recent coral cover also varied significantly among subregions (ANOVA, p < 0.0001; Fig. 4; see also Fig. S4). Subregional coral cover differences are concordant with a previous analysis of the Caribbean (Gardner et al. 2003). Assuming the historical coral cover baseline was similar across the region, this pattern of current spatial variability could be interpreted as evidence of variable rates of coral loss.

Recent coral cover was highest in the Gulf of Mexico (58.1 $\pm 3.5 \%$ from 2001 to $2005, \mathrm{n}=10$ surveys). The high cover in this subregion was likely due to the absence of Acropora spp. host populations in the Flower Garden Banks (until recently; Precht \& Aronson 2004), where most of the surveys from the Gulf of Mexico were conducted, which precluded white band disease from reducing Acropora spp. coral cover there (Aronson et al. 2005). The Flower Garden Banks reefs are also atypical sites because survey depths there were from 20 to $30 \mathrm{~m}$ (e.g. Dokken et al. 2003), more than twice the mean depth of most surveys in the database.

Recent coral cover was lowest in the Florida Keys (FLK; $8.6 \pm 0.4 \%$ from 2001 to $2005, \mathrm{n}=747$ surveys). This subregion was extensively sampled (50.6\% of all surveys performed from 1996 to 2006 were conducted in the FLK; Table S2) and this overrepresentation could have unduly influenced the Caribbean-wide analyses. Therefore, we also analyzed the trends from 1996 to 2005 in regional coral and macroalgal cover without the FLK data. This resulted in annual regional coral cover means as much as $13.1 \%$ higher than when the FLK data were included (Fig. 2C,D), but did not noticeably influence macroalgal cover values. Mean

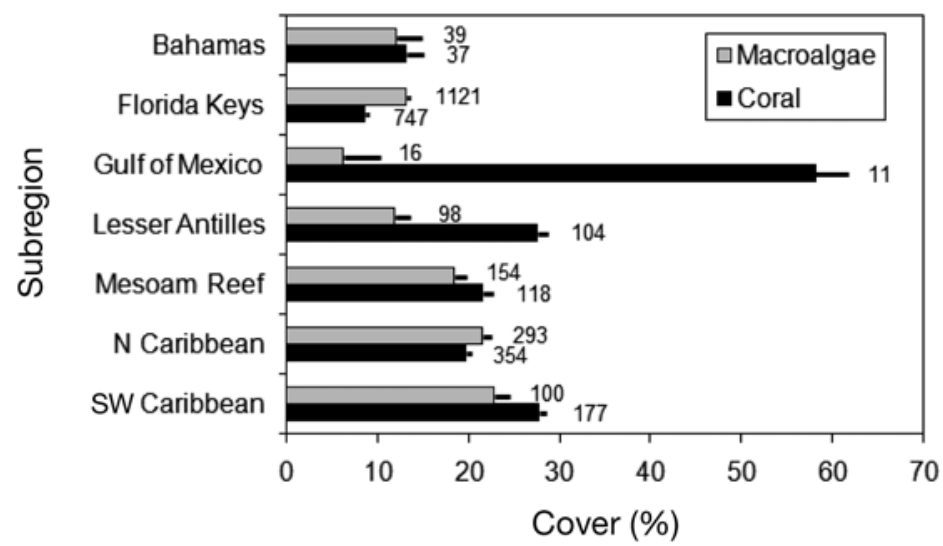

Fig. 4. Recent (2001 to 2005) macroalgal and coral cover in the 7 Caribbean subregions (Fig. 1). Values are means (+1 SE) and sample sizes (no. of sites) are shown to the right of the bars. Mesoam Reef: Mesoamerican Reef; N Caribbean: Northern Caribbean; SW Caribbean: Southwestern Caribbean regional Caribbean coral cover without the FLK data from 1996 to 2005 was $21.8 \pm 0.3 \%$.

The southeastern Caribbean experienced a severe warming event in late 2005, with levels of thermal stress exceeding standard bleaching thresholds (Fig. 1B; Donner et al. 2007, Wilkinson \& Souter 2008). This led to widespread coral bleaching, subsequent coral disease outbreaks, and moderate to severe local coral mortality and loss in some locations, including the US Virgin Islands and the Lesser Antilles (Miller et al. 2006, Wilkinson \& Souter 2008). There was a minor regional reduction in coral cover in 2006 (Fig. 2C), which could have been caused in part by coral mortality in several subregions, particularly those that experienced the most severe temperature anomalies (Fig. 1; see also Fig. S4), e.g. the Northern Caribbean (-6.0\% absolute cover from 2005 to 2006) and the Lesser Antilles $(-3.8 \%$ absolute cover). However, we did not have enough post-bleaching event data to reliably estimate subregional declines since 2005 (Table S2).

\section{Monitored sites}

Our analysis was primarily based on reefs that were randomly selected and surveyed only once. The results of such randomized population sampling can be generalized to a greater degree than those from longitudinal monitoring studies. However, randomized sampling has some drawbacks, including sensitivity to sample composition. Minor, short-term fluctuations in coral and macroalgal cover (Fig. 2; see also Fig S4) could be due to the subpopulation of reefs that were surveyed in a given year, rather than to real year-to-year changes in community state. Although non-random initial site selection can cause similar biases, monitoring studies are generally less sensitive to sample composition and have several advantages, including greater power to detect small changes in community state. Unfortunately, there are still relatively few quantitative reef monitoring programs and most are focused on well-studied reefs within Marine Protected Areas.

Spatio-temporal patterns from the subset of 376 monitored reefs are very similar to those from the entire database (Fig. S5 in the supplement, www.int-res.com/articles/suppl/m402 p115_app.pdf) and are concordant with our general conclusions. The regional trends from the sites monitored from 1996 to 2006 indicate that, since 1996, there has been very little temporal variation in both coral $(\mathrm{n}=331)$ and macroalgal cover $(n=215)$ and the trends reinforce the finding that reefs in the Caribbean entered a period of general regional stasis in 
the mid-1990s, at least in terms of coral and macroalgal cover. Linear repeated-measures regression analyses indicate that there was no significant change in coral cover $(\mathrm{p}=0.32, \mathrm{n}=331$ reefs) or macroalgal cover ( $\mathrm{p}=0.109, \mathrm{n}=215$ reefs) from 1996 to 2006 across the region (Table S4 in the supplement, www.int-res.com/ articles/suppl/m402p115_app.pdf). We also analyzed monitoring data from each subregion independently from 1996 to 2006; in most cases, there was no significant change in cover (Tables S5 \& S6 in the supplement, www.int-res.com/articles/suppl/m402p115_app. pdf. There was a statistically, although perhaps not ecologically, significant decrease in both coral and macroalgal cover in the intensively monitored Florida Keys. Coral cover slightly increased in the Northern Caribbean and decreased in the Lesser Antilles and the Southwestern Caribbean. Otherwise, our regression analyses of the monitoring data suggest that there have been few other signs of temporal change within subregions since 1996.

\section{CONCLUSIONS}

The first meta-analysis of Caribbean hard coral cover documented a reduction from $\sim 50 \%$ in 1977 to $\sim 10 \%$ in 2001 (Gardner et al. 2003). Our study built on that work by adding surveys from an additional 1699 sites and macroalgal data and by expanding the analysis to 2006. The timing of coral loss we documented is consistent with the hypothesis that the acroporid white band epizootic was the primary cause of hard coral cover loss in the Caribbean (Aronson \& Precht 2006). Likewise, the regional macroalgal bloom that occurred several years after the disease-induced Diadema antillarum die-off supports the argument that a reduction in herbivory, rather than increased nutrient availability, caused the observed increases in macroalgal cover (Hughes et al. 1999). Therefore, disease, whether natural or exacerbated by human activities, appears to have been the primary driver of regional-scale changes in Caribbean reef benthic communities over the last $35 \mathrm{yr}$. Our results indicate that, since these 2 major disturbances, regional coral and macroalgal benthic coverage has been relatively stable. However, the future of Caribbean reefs is uncertain. There are many factors besides disease that could cause further changes in reef benthic community structure, including climate change, ocean acidification, and direct anthropogenic stressors like overfishing and nutrient pollution (Hughes et al. 2003). Although our results could be interpreted as relatively good news, the observed regional pattern could also be a temporary plateau preceding a potential collapse in coral cover.
Acknowledgements. We thank K. France, R. Katz, L. Ladwig, S. C. Lee, M. I. O'Connor, C. Shields, G. Smelick, I. Vu, and A. M. Melendy for assistance with this project, and J. C. Lang, G. Hodgson, W. F. Precht, and W. K. Fitt for very helpful comments on this paper. We are especially grateful to everyone who shared data with us, including Reef Check, AGRRA, Florida CREMP, the scientists and data managers who communicated with us personally, and all the volunteers and researchers who collected the data. This project was funded in part by the National Science Foundation, an Environmental Protection Agency STAR fellowship to E.R.S., and the University of North Carolina at Chapel Hill.

\section{LITERATURE CITED}

Alvarez-Filip L, Dulvy NK, Gill JA, Côté IM, Watkinson AR (2009) Flattening of Caribbean coral reefs: region-wide declines in architectural complexity. Proc Biol Sci 276: 3019-3025

Aronson RB, Precht WF (2001) White-band disease and the changing face of Caribbean coral reefs. Hydrobiologia 460:25-38

Aronson RB, Precht WF (2006) Conservation, precaution, and Caribbean reefs. Coral Reefs 25:441-450

Aronson RB, Precht WF, Macintyre IG, Murdoch TJT (2000) Ecosystems—coral bleach-out in Belize. Nature 405:36

Aronson RB, Precht WF, Toscano MA, Koltes KH (2002) The 1998 bleaching event and its aftermath on a coral reef in Belize. Mar Biol 141:435-447

Aronson RB, Macintyre IG, Wapnick CM, O'Neill MW (2004) Phase shifts, alternative states, and the unprecedented convergence of two reef systems. Ecology 85:1876-1891

Aronson RB, Precht WF, Murdoch TJT, Robbart ML (2005) Long-term persistence of coral assemblages on the Flower Garden Banks, northwestern Gulf of Mexico: implications for science and management. Gulf Mex Sci 23:84-94

Bruno JF, Selig ER (2007) Regional decline of coral cover in the Indo-Pacific: timing, extent, and subregional comparisons. PLoS ONE 2(8):e711. doi: 10.1371/journal.pone.0000711

> Bruno JF, Sweatman H, Precht WF, Selig ER, Schutte VGW (2009) Assessing evidence of phase shifts from coral to macroalgal dominance on coral reefs. Ecology 90: $1478-1484$

> Carpenter RC (1990) Mass mortality of Diadema antillarum. Mar Biol 104:67-77

Carpenter RC, Edmunds PJ (2006) Local and regional scale recovery of Diadema promotes recruitment of scleractinian corals. Ecol Lett 9:271-280

Côté IM, Gill JA, Gardner TA, Watkinson AR (2005) Measuring coral reef decline through meta-analyses. Philos Trans R Soc Lond B 360:385-395

Dokken QR, MacDonald IR, Tunnell JW Jr, Wade T and others (2003) Long-term monitoring at the East and West Flower Garden Banks, 1998-2001. Final report, U.S. Department of the Interior, Minerals Management Service, Gulf of Mexico OCS Region, New Orleans, LA

Donner SD, Knutson TR, Oppenheimer M (2007) Modelbased assessment of the role of human-induced climate change in the 2005 Caribbean coral bleaching event. Proc Natl Acad Sci USA 104:5483-5488

Edmunds PJ (2007) Evidence for a decadal-scale decline in the growth rates of juvenile scleractinian corals. Mar Ecol Prog Ser 341:1-13

Edmunds PJ, Bruno JF (1996) The importance of sampling scale in ecology: kilometer-wide variation in coral reef communities. Mar Ecol Prog Ser 143:165-171 
Edmunds PJ, Elahi R (2007) The demographics of a 15-year decline in cover of the Caribbean reef coral Montastrea annularis. Ecol Monogr 77:3-18

Endean R (1977) Acanthaster planci infestations of reefs of the Great Barrier Reef. In: Taylor DL (ed) Proceedings of the 3rd international coral reef symposium. University of Miami, Miami, FL, p 185-191

Fabricius KE (2005) Effects of terrestrial runoff on the ecology of corals and coral reefs: review and synthesis. Mar Pollut Bull 50:125-146

Gardner TA, Côté IM, Gill JA, Grant A, Watkinson AR (2003) Long-term region-wide declines in Caribbean corals. Science 301:958-960

Ginsburg RN (ed) (1993) Global aspects of coral reefs: health, hazards and history. University of Miami, Miami, FL

$>$ Grigg RW (1994) Effects of sewage discharge, fishing pressure and habitat complexity on coral ecosystems and reef fishes in Hawaii. Mar Ecol Prog Ser 103:25-34

Grigg RW, Dollar SJ (2005) Reassessing U.S. coral reefs. Science 308:1740-1742

Haley MP, Solandt JL (2001) Population fluctuations of the sea urchin Diadema antillarum and Tripneustes ventricosus at Discovery Bay, Jamaica: a case of biological succession? Caribb J Sci 37:239-245

Halpern BS, Walbridge S, Selkoe KA, Kappel CV and others (2008) A global map of human impact on marine ecosystems. Science 319:948-952

Hodgson G, Hill J, Kiene W, Maun L and others (2006) Instruction manual: a guide to coral reef monitoring. Reef Check Foundation, Pacific Palisades, CA

Hoegh-Guldberg O, Mumby PJ, Hooten AJ, Steneck RS and others (2007) Coral reefs under rapid climate change and ocean acidification. Science 318:1737-1742

Hughes TP (1994) Catastrophes, phase shifts, and large-scale degradation of a Caribbean coral reef. Science 265: $1547-1551$

Hughes TP, Keller BD, Jackson JCB, Boyle MJ (1985) Mass mortality of the echinoid Diadema antillarum Philippi in Jamaica. Bull Mar Sci 36:377-384

Hughes TP, Szmant AM, Steneck R, Carpenter RC, Miller SL (1999) Algal blooms on coral reefs: What are the causes? Limnol Oceanogr 44:1583-1586

Hughes TP, Baird AH, Bellwood DR, Card M and others (2003) Climate change, human impacts, and the resilience of coral reefs. Science 301:929-933

Idjadi JA, Edmunds PJ (2006) Scleractinian corals as facilitators for other invertebrates on a Caribbean reef. Mar Ecol Prog Ser 319:117-127

Jackson JBC, Kirby MX, Berger WH, Bjorndal KA and others (2001) Historical overfishing and the recent collapse of coastal ecosystems. Science 293:629-637

Jones GP, McCormick MI, Srinivasan M, Eagle JV (2004) Coral decline threatens fish biodiversity in marine reserves. Proc Natl Acad Sci USA 101:8251-8253

Lam K, Shin PKS, Bradbeer R, Randall D, Ku KKK, Hodgson P, Cheung SG (2006) A comparison of video and point intercept transect methods for monitoring subtropical coral communities. J Exp Mar Biol Ecol 333: 115-128

Lang JL (2003) Status of coral reefs in the western Atlantic: results of initial surveys, Atlantic and Gulf Rapid Reef Assessment (AGRRA) Program. Atoll Res Bull 496:1-651

Lessios HA (1988) Mass mortality of Diadema antillarum in the Caribbean: What have we learned? Annu Rev Ecol Syst 19:371-393

Editorial responsibility: Tim McClanahan,

Mombasa, Kenya
Liddell WD, Ohlhorst SL (1992) Ten years of disturbance and change on a Jamaican fringing reef. In: Richmond RH (ed) Proceedings of the 7 th international coral reef symposium. University of Guam Press, Guam, p 149-155

Maliao RJ, Turingan RG, Lin J (2008) Phase-shift in coral reef communities in the Florida Keys National Marine Sanctuary (FKNMS), USA. Mar Biol 154:841-853

Miller MW, Aronson RB, Murdoch TJT (2003) Monitoring coral reef macroalgae: different pictures from different methods. Bull Mar Sci 72:199-206

Miller J, Waara R, Muller E, Rogers C (2006) Coral bleaching and disease combine to cause extensive mortality on reefs in US Virgin Islands. Coral Reefs 25:418

- Myhre S, Acevedo-Gutiérrez A (2007) Recovery of sea urchin Diadema antillarum populations is correlated to increased coral and reduced macroalgal cover. Mar Ecol Prog Ser 329:205-210

> Norström AV, Nyström M, Lokrantz J, Folke C (2009) Alternative states on coral reefs: beyond coral-macroalgal phase shifts. Mar Ecol Prog Ser 376:295-306

Paddack M, Reynolds J, Aguilar C, Appledoorn R and others (2009) Recent region-wide declines in Caribbean reef fish abundance. Curr Biol 19:590-595

Pandolfi JM, Bradbury RH, Sala E, Hughes TP and others (2003) Global trajectories of the long-term decline of coral reef ecosystems. Science 301:955-958

Porter JW, Meier OW (1992) Quantification of loss and change in Floridian reef coral populations. Am Zool 32: $625-640$

Pratchett MS, Munday PL, Wilson SK, Graham NAJ and others (2008) Effects of climate-induced coral bleaching on coral-reef fishes - ecological and economic consequences. Oceanogr Mar Biol Annu Rev 46:251-296

Precht WF, Aronson RB (2004) Climate flickers and range shifts of reef corals. Front Ecol Environ 2:307-314

Precht WF, Miller SL, Aronson RB, Bruno JF, Kaufman L (2005) Reassessing US coral reefs. Science 308: $1740-1742$

Rasband WS (2006) ImageJ. US National Institutes of Health, Bethesda, MD

> Rogers CS, Miller J (2006) Permanent 'phase shifts' or reversible declines in coral cover? Lack of recovery of two coral reefs in St. John, US Virgin Islands. Mar Ecol Prog Ser 306:103-114

- Spalding MD, Fox HE, Allen GR, Davidson N and others (2007) Marine ecoregions of the world: a bioregionalization of coastal and shelf areas. Bioscience 57:573-583

Steneck RS (1988) Herbivory on coral reefs: a synthesis. In: Choat JH, Barnes D, Borowitzka MA, Coll JC and others (eds) Proceedings of the 6th international coral reef symposium. 6th International Coral Reef Symposium Executive Committee, Townsville, p 37-49

Wilkinson CR (1992) Coral reefs of the world are facing widespread devastation: Can we prevent this through sustainable management practices? In: Richmond RH (ed) Proceedings of the 7 th international coral reef symposium. University of Guam Press, Guam, p 11-21

Wilkinson CR, Souter D (2008) Status of Caribbean coral reefs after bleaching and hurricanes in 2005. Global Coral Reef Monitoring Network and Reef and Rainforest Research Centre, Townsville

Woodley JD, Chornesky EA, Clifford PA, Jackson JBC and others (1981) Hurricane Allen's impact on Jamaican coral reefs. Science 214:749-755

Submitted: May 18, 2009; Accepted: November 23, 2009

Proofs received from author(s): February 18, 2010 